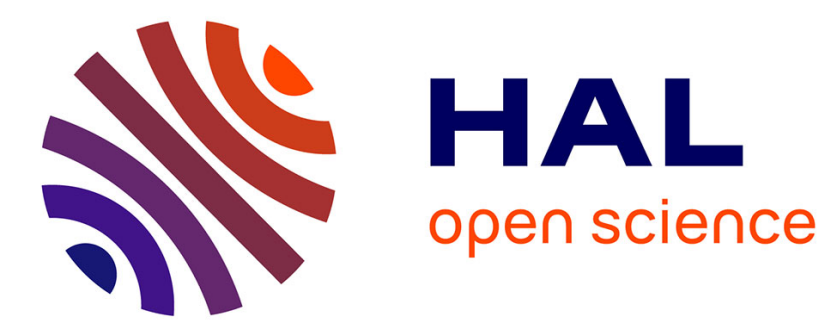

\title{
Creation of stable associations between perennial ryegrass or tall fescue and fungal endophytes
}

Walid Naffaa, Claude Astier, Catherine Ravel, Jean-Jacques Guillaumin

\section{To cite this version:}

Walid Naffaa, Claude Astier, Catherine Ravel, Jean-Jacques Guillaumin. Creation of stable associations between perennial ryegrass or tall fescue and fungal endophytes. Agronomie, 1999, 19 (2), pp.133-144. hal-00885921

\section{HAL Id: hal-00885921 \\ https://hal.science/hal-00885921}

Submitted on 1 Jan 1999

HAL is a multi-disciplinary open access archive for the deposit and dissemination of scientific research documents, whether they are published or not. The documents may come from teaching and research institutions in France or abroad, or from public or private research centers.
L'archive ouverte pluridisciplinaire HAL, est destinée au dépôt et à la diffusion de documents scientifiques de niveau recherche, publiés ou non, émanant des établissements d'enseignement et de recherche français ou étrangers, des laboratoires publics ou privés. 


\title{
Creation of stable associations between perennial ryegrass or tall fescue and fungal endophytes
}

\author{
Walid Naffaa ${ }^{\mathrm{a}}$, Claude Astier ${ }^{\mathrm{b}}$, Catherine Ravel $^{\mathrm{b}}$, Jean-Jacques Guillaumin ${ }^{\mathrm{a}^{*}}$ \\ ${ }^{a}$ Unité de pathologie végétale et mycologie, centre de Clermont-Ferrand, Inra, 234, avenue du Brézet, \\ 63039 Clermont-Ferrand cedex 02, France \\ ${ }^{b}$ Unité d'amélioration des plantes, centre de Clermont-Ferrand, Inra, 234, avenue du Brézet, \\ 63039 Clermont-Ferrand cedex 02, France
}

(Received 1 March 1998; accepted 15 January 1999)

\begin{abstract}
The ability of 15 isolates of endophytic fungi isolated from ten species of grasses to form compatible associations following artificial infection with perennial ryegrass (Lolium perenne, cv. Vigor) and tall fescue (Festuca arundinacea, cv. Clarine) was examined. Twenty-two associations were obtained, only eight failed. The species Neotyphodium lolii, N. coenophialum, LpTG-2, Epichloe festucae, E. bromicola and Gliocladium-like endophyte, could be associated with both $L$. perenne and $F$. arundinacea. Acremonium sp. from $L$. persicum could be associated with $L$. perenne only. The observation of infected plants after 6 months and the study of mycelial transmission to the seeds showed the stability of the following associations: tall fescue with $N$. coenophialum and $N$. lolii, perennial ryegrass with N. lolii, LpTG-2, Epichloe festucae and Gliocladium-like. Acremonium sp. from Lolium persicum was not able to survive in $L$. perenne for a long time. Various aspects of partial incompatibility were observed among the associations: tall fescue/LpTG-2, tall fescue / Gliocladium-like and perennial ryegrass/ $N$. coenophialum. The study suggests that selection of suitable endophytic strains for fodder grasses can be enlarged to endophytes naturally harboured by other host species. (C Inra/Elsevier, Paris.)
\end{abstract}

Lolium perenne / Festuca arundinacea / endophytes / artificial infection / seed transmission

Résumé - Infection artificielle du ray-grass anglais et de la fétuque élevée par des champignons endophytes provenant de dix espèces différentes de graminées. On a examiné la capacité de 15 isolats d'endophytes, provenant de dix espèces de graminées différentes, à former des associations avec le ray-grass anglais (Lolium perenne, cv. Vigor) et la fétuque élevée (Festuca arundinacea, $\mathrm{cv}$. Clarine). Vingt-deux associations sur trente ont pu être obtenues. Les taxa Neotyphodium lolii, $N$. coenophialum, LpTG-2, Epichloe festucae, E. bromicola et Gliocladium-like ont été capables de s'associer avec $L$. perenne et $F$. arundinacea. Acremonium sp. provenant de $L$. persicum a pu s'associer avec $L$. perenne, mais non avec $F$. arundinacea. L'observation après six mois des plantes inoculées et l'étude de la transmission du

Communicated by Yves Brygoo (Versailles, France)

* Correspondence and reprints

guillaum@valmont.clermont.inra.fr 
champignon aux graines ont montré la stabilité de six associations: la fétuque élevée avec $N$. coenophialum et $N$. lolii, le ray-grass anglais avec $N$. lolii, LpTG-2, Epichloe festucae et le Gliocladium-like. L'isolat d'Acremonium sp. provenant de Lolium persicum ne s'est pas maintenu au-delà de quelques mois sur $L$. perenne. Différentes manifestations d'incompatibilité ont été observées sur les associations: fétuque élevée / LpTG-2, fétuque élevée / Gliocladium-like et ray-grass anglais / N. coenophialum. Cette étude montre que la sélection de souches d'endophytes pour introduction dans les graminées fourragères peut être étendue à des endophytes naturellement hébergés par d'autres espèces de graminées. (C Inra/Elsevier, Paris.)

Lolium perenne / Festuca arundinacea / endophytes / inoculation artificielle / transmission dans les graines

\section{INTRODUCTION}

Endophytic fungi belonging to the genus Neotyphodium Glenn, Bacon \& Hanlin (= Acremonium sect. Albo-lanosa Morgan-Jones \& Gams) establish mutualistic associations with many grasses of the subfamily Festucoideae [10, 14]. Neotyphodium species are closely related to species of Epichloe (family of Clavicipitaceae), with which they share many characteristics. However, the sexual stage (perithecia produced in mycelial stromata surrounding host tillers) is lacking in Neotyphodium species, which are regarded as asexual descendants of Epichloe [34]. The term 'e-endophytes' is often used to regroup both Neotyphodium and Epichloe species.

Two species of fodder grasses have been more thoroughly studied as regards their endophytes: tall fescue (Festuca arundinacea) and perennial ryegrass (Lolium perenne). The former species has been shown to harbour three different taxonomical groups or TG: FaTG-1 or Neotyphodium coenophialum, FaTG-2 and FaTG-3, which were distinguished on the basis of their macro- and micromorphological characteristics, mycotoxin analysis and isozyme phenotypes [6, 27, 33]. Although FaTG-2 and FaTG-3 are likely to be species, they did not receive latin names. Using the same criteria, two e-endophytes were described from Lolium perenne: LpTG-1 or Neotyphodium lolii and LpTG-2, which did not receive a latin name $[5,6,20]$. Several species have also been described within the genus Epichloe, among which the more common are the parasitic species E. typhina (Pers.:Fr.) Tul., which infects many grass species and the pleiomorphic species (generally symptomless) E. festucae Leuchtmann, Schardl and Siegel, found in several wild species of Festuca [24]. An endophyte of Koeleria cristata was also referred to as E. festucae from its morphological characteristics, isozyme pattern and ITS sequence [29].

The Neotyphodium species are considered to be mutualistic [9] because they improve the resistance of their hosts against abiotic stresses (drought, nitrogen depletion, etc.) and also confer on their hosts, through the presence of mycotoxins, resistance to insects and herbivorous mammals [36, 38].

Certain grass species also harbour non-clavicipitaceous fungal endophytes which are less frequent than e-endophytes and belong to two different types: i) the p-endophytes include Gliocladium-like isolates in perennial ryegrass and Phialophora-like isolates in Festuca spp. [19, 37] (the letter 'p' referring to the penicillate disposition of the conidiophores, common to Gliocladium-like and Phialophora-like isolates); ii) the a-endophytes belonging to Acremonium sp. sensu stricto have only been found in annual species of Lolium [28, 29]. The p-endophytes are frequently found in cosymbiosis with e-endophytes and they do not seem to synthesize mycotoxins. According to Schmidt [35], Phialophora-like endophyte of Festuca pratensis negatively affects its hosts. Recently, Malinowski et al. [26] reported contrasting results under controlled conditions which were explained by specific interactions between meadow fescue genotypes and Phialophora-like strains. The aendophytes are still poorly known as concerns their relationships with their hosts.

The presence of e-endophytes has contrasting implications for agriculture: they improve the resistance of their hosts to abiotic and biotic stresses, and especially to insects and nematodes through two groups of mycotoxins: peramine and lolines. 
However, through two other groups of toxins (ergotic compounds and lolitrems), they can cause severe toxicoses in livestock consuming infested forage. Cases of toxicosis are common in the USA and New Zealand [1,12], and they have recently been observed in Europe [31]. However, it was shown that a large variability (both at the intra- and interspecific levels) exists among e-endophytes as concerns their capacity to synthesize mycotoxins $[6,32]$. Therefore, plant breeders can select endophyte strains with a low rate of synthesis for ergotic compounds and lolitrems and try to introduce them into valuable cultivars of ryegrass and fescue in order to use the beneficial effect of this mutualistic symbiosis [13]. However, this strategy implies that these selected strains could easily be introduced into hosts by artificial inoculation.

Although natural infection of grasses by Neotyphodium in nature seems to occur entirely through seed transmission, artificial infection could be obtained by inoculating seedlings $[4,7,20]$, mature plants [30] and callus cultures [16]. This artificial infection could have important practical consequences, as it could be the first step towards the creation of new associations between commercial grass cultivars and endophyte isolates selected for their harmlessness to mammals and beneficial effects on the host. As stated by Fletcher and Easton [13], a high rate (close to $100 \%$ ) of transmission of the fungus to the seeds is a necessary (but not sufficient) condition to hope to use in practice a new association. Recently, Koga et al. [18] showed that the resistance to some insects could be transmitted by artificial inoculation of endophytes. In New Zealand, by checking a high number of natural isolates of the endophytes of perennial ryegrass, it was possible to select certain strains which were potentially of interest because they were free of the two main groups of mammalian mycotoxins [13].

In general, inoculations are most successful when isolates are transferred between closely related grasses [23]. However, some evidence of incompatibility can be observed when an isolate is introduced into another host, even if it is not very distant from the original one; incompatibility can concern either the fungus which shows distorted, vacuolized hyphae, as when $N$. coenophialum is introduced into Lolium perenne $[4,17]$ or the host; for instance, Christensen [4], observed the death of host tissues of the shoot apices of tall fescue infected with $N$. uncinatum or LpTG-2, while Christensen et al. [7] reported that certain isolates of $E$. festucae caused increased mortality, stunted growth and chlorotic leaf symptoms on infected seedlings of perennial ryegrass, tall fescue and meadow fescue. These different manifestations of incompatibility could explain that certain associations are not stable and can disappear over time (especially at the critical level of seed transmission). Anyhow, in most of these studies (with the exception of Koga et al. [18]), the transmission of the mycelium of the endophyte to the seeds of the inoculated plant has not been studied, so it is not really possible to assess the stability of these artificial associations.

Our objective was to study the possibility of creating associations as diverse as possible and to assess the stability of these associations by observation of transmission of the endophyte to the seeds of the plant. Infection of seedlings of ryegrass and tall fescue was tried with 15 isolates belonging to ten different fungal species distributed between the three groups: e-, p- and a-endophytes.

\section{MATERIALS AND METHODS}

\subsection{Plant material}

Festuca arundinacea cv. Clarine and Lolium perenne cv. Vigor were used in the study. For both species, endophyte-free seeds were obtained from endophyte-free plants. Vigor is a cultivar that is currently endophytefree. As concerns Clarine, the endophyte-free plants from which the seeds were collected were obtained by Raynal (pers. comm.) from a selection within a partially infected population. In addition, 100 seeds of both cultivars were examined to verify that they were really free of endophytes.

\subsection{Fungal isolation}

The 15 isolates were freshly isolated from their hosts for the experiment. A majority of isolates were obtained 
from the leaf sheaths of growing plants either collected in nature (Frn-1, Fg-1a, Kc-1) or maintained in nurseries (Lp-1, Lp-12, Lp-13, Lp-14, Lp-80, Fa-3, Fa-6), according to the method of Clark et al. [8]. Lpr-1 was obtained from seeds [29] and Dg-1, Pn-1, Pd-1, Be-1 from mycelial stromas [8].

\subsection{Fungal isolates}

Fifteen isolates from ten species of Poaceae were used in this study (table I). These isolates were distributed between the main groups of endophytes reported in Poaceae (Neotyphodium spp., Epichloe spp., p-endophytes and a-endophytes). In the experiment, they were identified by several characteristics: their macromorphology in culture on PDA, their asexual sporulation in vitro and the morphology and size of their conidia, and their isozyme pattern for three systems: MDH (malate deshydrogenase), PGI (phosphoglucose isomerase) and PGM (phosphoglucomutase).

The characteristics of the isolates were as follows.

- The two Neotyphodium lolii isolates (Lp-13 and Lp14) are characterized by their very slow growth on PDA, brain-like, cream-coloured colonies, absence of sporulation in culture and specific patterns of MDH, PGI and PGM.

- The isolates belonging to LpTG-2 (Lp-1 and Lp-12) grow slowly and form white, fluffy colonies on PDA. They sporulate in culture, their conidia are scarce, kid- ney-like, 6-7 $\mu \mathrm{m}$ in length. The isolates of this group have typical isozyme patterns on MDH and PGM.

- The $N$. coenophialum isolates are similar to those of LpTG-2 with regards to their growth rate, the aspect of their thalli on PDA and their shape of conidia (kidneylike). They differ from LpTG-2 by the large size of their conidia ( $8-12 \mu \mathrm{m}$ in length) and their isozyme patterns.

- Three isolates (Frn-1, Fg-1 a and Kc-1) were considered as belonging to Epichloe festucae. They grow fairly rapidly on PDA, the thalli are white and fluffy on the upper side, brown on the lower side. They sporulate in culture and their kidney-like conidia are similar to those of LpTG-2, although slightly smaller (4-6 $\mu \mathrm{m}$ in length). Although Kc-1 has been isolated from a species (Koeleria cristata) not belonging to the genus Festuca and the tribe Poaeae, it has been identified as E. festucae by Naffaa et al. [29] from all its characteristics, including isozyme patterns.

- The isolates belonging to Epichloe typhina (Dg-1 and Pn-1, isolated from Dactylis glomerata and Poa nemoralis, respectively) cannot be distinguished from those of Epichloe festucae by the shape and size of their conidia. However, their isozyme patterns are different.

- The isolate Be-1 was obtained from a stroma on Bromus erectus, it also shows the same macroscopical aspect in culture and the same shape and size of conidia as E. typhina. This strain probably belongs to the species Epichloe bromicola, recently described by Leuchtmann and Schardl [25]. Its MDH and PGI patterns are the same as those of E. festucae, its PGM pattern is the same as that of E. typhina.

Table I. List of isolates of endophytes and their host species.

\begin{tabular}{lll}
\hline Isolate & Endophyte & Host species \\
\hline $\mathrm{Lp}-1$ & LpTG-2 & Lolium perenne \\
$\mathrm{Lp}-12$ & LpTG-2 & Lolium perenne \\
$\mathrm{Lp}-13$ & Neotyphodium lolii & Lolium perenne \\
$\mathrm{Lp}-14$ & Neotyphodium lolii & Lolium perenne \\
$\mathrm{Lp}-80$ & Gliocladium-like & Lolium perenne \\
$\mathrm{Fa}-6$ & Neotyphodium coenophialum & Festuca arundinacea cv. Clarine \\
$\mathrm{Fa}-3$ & Neotyphodium coenophialum & Festuca arundinacea \\
$\mathrm{Frn}-1$ & Epichloe festucae & Festuca rubra nigrescens \\
$\mathrm{Fg}-1 \mathrm{a}$ & Epichloe festucae & Festuca gigantea \\
$\mathrm{Kc}-1$ & Epichloe festucae? & Koeleria cristata \\
$\mathrm{Dg}-1$ & Epichloe typhina & Dactylis glomerata \\
$\mathrm{Pn}-1$ & Epichloe typhina & Poa nemoralis \\
$\mathrm{Be}-1$ & Epichloe bromicola & Bromus erectus \\
$\mathrm{Pd}-1$ & Epichloe sp. & Puccinellia distans \\
$\mathrm{Lpr}-1$ & Acremonium sp. & Lolium persicum \\
\hline
\end{tabular}


- The isolate Pd-1 was isolated from a stroma on Puccinellia distans. It is also similar to E. typhina by its aspect in culture, growth rate and conidia, its isozyme patterns have not been determined.

- The isolate Lp- 80 belonging to p-endophytes does not sporulate in vitro, it grows slowly on PDA at $23{ }^{\circ} \mathrm{C}$, but more rapidly at $18{ }^{\circ} \mathrm{C}$. The colonies are white, cottony and convex. The isoenzyme patterns are typical of p-endophytes.

- The isolate Lpr-1 belonging to a-endophytes is well characterized by its rapid growth on PDA, the pinkish, fluffy aspect of its mycelium on this medium (with yellow pigment on the lower side), the abundant sporulation in culture, rod-shaped conidia and isozyme patterns [29].

The isolates are conserved at Inra Clermont-Ferrand.

\subsection{Inoculation of plants}

Endophyte-free seeds were surface sterilized by soaking in $6 \%$ sodium hypochlorite for $4 \mathrm{~h}$ and rinsing in sterile water. Seeds were then placed on water agar in Petri dishes (ten per dish), and incubated in darkness at $23{ }^{\circ} \mathrm{C} \pm 1$ for 7 days. During this time, the seeds germinated and those that appeared contaminated with fungi or bacteria were removed. A longitudinal slit was cut through the tissue of the young seedlings at the junction of the mesocotyl and coleoptile and a drop of solution of ground mycelium in sterile water was placed in the slit. The mycelium used for inoculation was taken at the periphery of the colonies. For those isolates which sporulate in vitro (all isolates except Lp-13, Lp-14 and Lp-80), the inoculum probably consisted of a mixture of mycelium and conidia.

Control seedlings received similar treatments except that no mycelium was placed on the slit of the seedlings.

After inoculation the seedlings were incubated for 4 days in darkness, then 3 days in light prior to planting in pots. Then, the plants were, after adaptation, grown in the greenhouse, in summertime conditions (temperatures between 22 and $28^{\circ} \mathrm{C}$ ), and watered twice a week.

\subsection{Detection of endophytes and transmission to the seeds}

The seedlings were submitted to a first examination approximately 8 weeks after infection for the presence of intercellular hyphae characteristic of the used endo- phytes. Epidermal strips removed from leaf sheaths were mounted in aniline blue stain, as described by Clark et al. [8] and examined with a compound microscope. Confirmation of successful inoculation was obtained by isolating fungi from surface-sterilized leaf sheaths on PDA, and by comparing conidial dimensions and colony characteristics with those of the original isolates. Isozyme profiles of these isolates were also compared with those of the original isolates using the methods described by Leuchtmann and Clay [22].

Thirteen out of the 22 successful associations were selected in order to study the transmission of mycelium to the seeds (tables $I I$ and $I I I$ ). The selection was made so as to plant in the field one representative association per host plant/endophyte species combination.

The E+ plants of these 13 associations were conserved for about 4 months in the greenhouse before planting in the field. During this period, the plants of the two associations with Epichloe bromicola (Clarine/Be-1 and Vigor/Be-1) died, so that only 11 associations were planted, 6 months after inoculation (in the autumn of 1996). Just before planting, these plants were submitted to a second examination for the presence of endophyte and new isolations were carried out.

Transmission to the seeds was studied for these 11 associations in spring 1997 (table IV). Several plants (2-8) were randomly selected from each association. Three ears (ryegrass) or panicles (fescue) were randomly selected from each of these plants. About 20 seeds from each ear or panicle were examined, using the method of Clark et al. [8], for the presence of mycelium endophyte. The percentage of seeds showing mycelium and the confidence interval $(\alpha=5 \%)$ were calculated for each association. Generally, seeds from different plants and different ears or panicles of a given association were mixed and observed in bulks. However, for two associations which showed symptoms of partial incompatibility $(N$. coenophialum on perennial ryegrass and Gliocladium-like on tall fescue), the presence of the endophyte was checked separately on the seeds of the different plants and ears (or panicles). Seeds from noninfected plants (controls) were also examined.

\section{RESULTS}

\subsection{Success of artificial inoculation}

In total, 3855 seedlings (2 023 of Clarine + 1832 of Vigor) were inoculated. Of these, 1450 
Table II. Percentage of perennial rye-grass plants artificially infected with 15 isolates of endophytes obtained from ten species of grass (observation after 2 months).

\begin{tabular}{lcccccc}
\hline Fungus & Isolates & Natural host & $\begin{array}{c}\text { Number of } \\
\text { seedlings } \\
\text { inoculated }\end{array}$ & $\begin{array}{c}\text { Number of surviving } \\
\text { plants examined } \\
\text { after } 2 \text { months }\end{array}$ & $\begin{array}{c}\text { Percentageage Confidence } \\
\text { of infected } \\
\text { plants }(\%)\end{array}$ & $\begin{array}{c}\text { Interval } \\
(\alpha=5 \%)\end{array}$ \\
\hline LpTG-2 & Lp-1 & L. perenne & 289 & 188 & 3.7 & {$[0.01 ; 0.06]$} \\
& Lp-12* & L. perenne & 61 & 18 & 27.8 & {$[0.10 ; 0.52]$} \\
N. lolii & Lp-13* & L. perenne & 285 & 190 & 25 & {$[0.18 ; 0.31]$} \\
& Lp-14 & L. perenne & 43 & 8 & 11.1 & {$[0 ; 0.51]$} \\
Gliocladium-like & Lp-80* & L. perenne & 228 & 145 & 57.9 & {$[0.50 ; 0.66]$} \\
N. coenophialum & Fa-3 & F. arundinacea & 70 & 40 & 5 & {$[0.01 ; 0.19]$} \\
& Fa-6 $*$ & F. arundinacea & 199 & 147 & 10.9 & {$[0.06 ; 0,16]$} \\
E. festucae & Frn-1* & F. r. nigrescens & 122 & 97 & 90.7 & {$[0.83 ; 0.96]$} \\
& Fg-1a & F. gigantea & 71 & 43 & 18.6 & {$[0.06 ; 0.30]$} \\
E. festucae? & Kc-1 & K. cristata & 50 & 25 & 24 & {$[0.09 ; 0.46]$} \\
E. typhina & Dg-1 & D. glomerata & 78 & 51 & 0 & {$[0 ; 0.07]$} \\
& Pn-1 & P. nemoralis & 42 & 35 & 0 & {$[0 ; 0.11]$} \\
Epichloe sp. & Pd-1 & P. distans & 36 & 28 & 0 & {$[0 ; 0.10]$} \\
E. bromicola & Be-1 & B. erectus & 62 & 29 & 41.4 & {$[0.23 ; 0.60]$} \\
Acremonium sp. & Lpr-1 & L.persicum & 43 & 12 & 41.7 & {$[0.15 ; 0.73]$} \\
\hline
\end{tabular}

* Associations planted in field to obtain seeds (the plants with Be-1 died in the greenhouse before planting).

Table III. Percentage of tall fescue plants artificially infected with 15 isolates of endophytes obtained from ten species of grass (observation after 2 months).

\begin{tabular}{lcccccc}
\hline Fungus & Isolates & Natural host & $\begin{array}{c}\text { Number of } \\
\text { Seedlings } \\
\text { Inoculated }\end{array}$ & $\begin{array}{c}\text { Number of } \\
\text { plants examined } \\
\text { after } 2 \text { months }\end{array}$ & $\begin{array}{c}\text { Percentage } \\
\text { of infected } \\
\text { plants }(\%)\end{array}$ & $\begin{array}{c}\text { Confidence } \\
\text { interval } \\
(\alpha=5 \%)\end{array}$ \\
\hline LpTG-2 & Lp-1 & L. perenne & 221 & 169 & 9.5 & {$[0.06 ; 0.14]$} \\
& Lp-12 $(*)$ & L. perenne & 78 & 56 & 19.6 & {$[0.10 ; 0.34]$} \\
N. lolii & Lp-13 $(*)$ & L. perenne & 225 & 106 & 2.8 & {$[0 ; 0.06]$} \\
& Lp-14 & L. perenne & 46 & 21 & 0 & {$[0 ; 0.17]$} \\
Gliocladium-like & Lp-80 $\left(^{*}\right)$ & L. perenne & 240 & 145 & 86.2 & {$[0.80 ; 0.92]$} \\
N. coenophialum & Fa-3 & F. arundinacea & 59 & 46 & 6.5 & {$[0.01 ; 0.18]$} \\
& Fa-6* & F. arundinacea & 238 & 144 & 22.9 & {$[0.16 ; 0.30]$} \\
E. festucae & Frn-1* & F. r. nigrescens & 247 & 199 & 58.8 & {$[0.52 ; 0.66]$} \\
& Fg-1a & F. gigantea & 86 & 52 & 28.9 & {$[0.18 ; 0.45]$} \\
E. festucae? & Kc-1 & K. cristata & 58 & 26 & 53.9 & {$[0.33 ; 0.74]$} \\
E. typhina & Dg-1 & D. glomerata & 226 & 161 & 0 & {$[0 ; 0.02]$} \\
Epichloe sp. & Pn-1 & Poa nemoralis & 47 & 23 & 0 & {$[0 ; 0.17]$} \\
E. bromicola & Pd-1 & Puccinellia distans & 42 & 10 & 0 & {$[0 ; 0.30]$} \\
Acremonium sp. & Be-1 & B. erectus & 80 & 42 & 21.3 & {$[0.09 ; 0.47]$} \\
& Lpr-1 & L. persicum & 48 & 13 & 0 & {$[0 ; 0.26]$}
\end{tabular}

\footnotetext{
* Associations planted in field to obtain seeds (the plants with $\mathrm{Be}-1$ died in the greenhouse before plantation).
} 
died after transfer to the greenhouse while 2405 could be observed. Six hundred and thirty seedlings appeared to be infected (346 of Clarine +284 of Vigor), representing $26.2 \%$ of the seedlings which could be observed.

Fifteen associations were obtained in this study. LpTG-2, $N$. lolii, Gliocladium-like endophyte, $N$. coenophialum, Epichloe bromicola from B. erectus, $E$. festucae from $F$. rubra nigrescens, $F$. gigantea and Koeleria cristata, were able to form associations with $L$. perenne and $F$. arundinacea. We could not infect rye-grass or tall fescue with Epichloe typhina from Dactylis glomerata or Poa nemoralis, nor from Epichloe sp. from Puccinellia distans. Perennial ryegrass, but not tall fescue could be infected with Acremonium sp. from L. persicum (Lpr-1).

The percentage of inoculated seedlings in established associations varied greatly (tables $I I$ and $I I I$ ). Whatever the host, it was particularly high for the Gliocladium-like endophyte (Lp-80) and for one of the isolates of E. festucae (Frn-1).

In the particular case of Acremonium sp. (isolated from Lolium persicum), only 13 plants could be observed and the endophyte was found in five cases. The mycelial fragments were rare and restricted to the very base of the foliar sheaths.

After these first microscopic observations, reisolations were attempted from all observed plants. The results showed that $0-5 \%$ of apparently endophyte-free plants, according to microscopic observations, gave rise to mycelium after isolation. This phenomenon was frequent for the association Vigor/Lpr-1 (Acremonium sp. from L. persicum). On the other hand, colonies of endophyte were obtained from all plants in which mycelium had been observed. Morphological and isozyme study of five isolates from each association showed that all endophytes re-isolated from artificially infected plants were identical to the original isolates according to their conidial shape and dimensions, colony characteristics and isozyme patterns for $\mathrm{MDH}$, PGM and PGI.

Eleven associations were re-examined after about 6 months for the presence of intercellular hyphae. At this time, no mycelium was found in the association Vigor/Lpr-1 and the re-isolations were negative for this association. Most of the other initially successful infections of seedlings had persisted. However, Gliocladium-like endophyte had disappeared in $30 \%$ of infected plants of Clarine.

\subsection{Incompatibility reactions}

Two types of incompatibility reactions were observed. i) Hyphae of $N$. coenophialum were highly vacuolated in many plants of $L$. perenne with which this endophyte formed associations. Vacuolated hyphae were not observed for the other endophytes. ii) Stunted tillers were present in all $F$. arundinacea plants successfully inoculated with Gliocladium-like or LpTG-2, and of $L$. perenne plants inoculated with Gliocladium-like or $N$. coenophialum. Many stunted plants of $F$. arundinacea infected by Gliocladium-like occasionally produced apparently healthy tillers. No intercellular hyphae could be observed in these tillers and attempts to re-isolate from these tillers were unsuccessful. Of the $F$. arundinacea plants infected by LpTG-2, $62.5 \%$ died, this phenomenon not being observed with the other associations. Staining and observation of the mycelium of Gliocladium-like in $F$. arundinacea plants were very difficult. In contrast, the mycelium of this endophyte in L. perenne plants was easily stained and observed.

\subsection{Transmission of the endophytes to seeds of artificially infected plants}

The seeds from the different plants and ears were observed in bulk in nine cases out of 11 (table IV). For two particular associations (the Gliocladiumlike endophyte in seeds of $F$. arundinacea and $N$. coenophialum in seeds of $L$. perenne) which showed symptoms of incompatibility, the different plants and the different ears or panicles of one plant were checked separately and not in bulk (table $V$ ).

No mycelium was observed in the seeds for the association Vigor/Lpr-1 (Acremonium sp.). 
Table IV. Transmission rate of endophytes in seeds of artificially infected L. perenne and F. arundinacea.

\begin{tabular}{lccccc}
\hline Associations & $\begin{array}{c}\text { Number of } \\
\text { plants } \\
\text { examined }\end{array}$ & $\begin{array}{c}\text { Number of } \\
\text { seeds } \\
\text { examined }\end{array}$ & $\begin{array}{c}\text { Number of } \\
\text { seeds } \\
\text { infected }\end{array}$ & $\begin{array}{c}\text { Rate transmission } \\
\text { of the endophytes } \\
(\%)\end{array}$ & $\begin{array}{c}\text { Confidence } \\
\text { Interval } \\
(\alpha=5 \%)\end{array}$ \\
\hline Clarine + N. coenophialum (Fa-6) & 8 & 202 & 179 & 88.6 & {$[0.84 ; 0.94]$} \\
Clarine + LpTG-2 (Lp-12) & 3 & 75 & 70 & 93.3 & {$[0.83 ; 0.97]$} \\
Clarine + N. lolii (Lp-13) & 2 & 47 & 36 & 76.6 & {$[0.64 ; 0.88]$} \\
Clarine + Gliocladium-like (Lp-80) & 5 & 530 & 198 & 37.4 & {$[0.33 ; 0.41]$} \\
Clarine + E. festucae (Frn-1) & 6 & 156 & 122 & 78.2 & {$[0.72 ; 0.84]$} \\
Vigor + N. coenophialum (Fa-6) & 3 & 290 & 75 & 19.5 & {$[0.15 ; 0.24]$} \\
Vigor + LpTG-2 (Lp-12) & 3 & 290 & 290 & 100 & {$[0.99 ; 1]$} \\
Vigor + N. lolii (Lp-13) & 5 & 328 & 328 & 100 & {$[0.99 ; 1]$} \\
Vigor + Gliocladium-like (Lp-80) & 5 & 156 & 105 & 67.3 & {$[0.60 ; 0.74]$} \\
Vigor + E. festucae (Frn-1) & 5 & 328 & 328 & 100 & {$[0.99 ; 1]$} \\
Vigor + Acremonium sp. (Lpr-1) & 3 & 100 & 0 & 0 & {$[0 ; 0.04]$} \\
\hline
\end{tabular}

The other endophytes were generally transmitted at a high rate $(>67.3 \%)$ in $L$. perenne and $F$. arundinacea seeds. This rate reached $100 \%$ for some associations.

In the association $F$. arundinacea/Gliocladiumlike, all the seeds (from three different panicles) from plant number 4 were endophyte-free. However, on the other four plants, endophyteinfected seeds were found in all the panicles observed, the frequency of endophyte-infected seeds from a given panicle was fairly homogeneous and never equal to 0 or $100 \%$. The same situation was observed with the association $L$. perenne/ $N$. coenophialum: on plants numbers 3 and 4 , all the ears observed had $100 \%$ endophyte-free seeds while on plants numbers 1 and 2 , all the ears observed had at least a weak proportion of endophyte-infected seeds (table $V$ ).

\section{DISCUSSION}

This work demonstrates (through the observation of seed transmission) the stability of certain associations. Among the 20 associations attempted, 15 appeared to succeed after 2 months; however, the plants of the two associations with E. bromicola died later in the greenhouse. Leuchtmann [21] showed that initially successful infections of seedlings inoculated with endophytes from another host have failed to persist for more than 6-8 months. In the present study, in the association Vigor/Acremonium sp. (from $L$. persicum), the mycelium could be detected after 2 months, but not after 6 months, whatever the method (microscopic observation or re-isolation). Moreover, Gliocladium-like in $F$. arundinacea did not persisted in about $30 \%$ of infected plants. Of the other nine associations, the second microscopic observation (after 6 months) showed that the mycelium was still present. These include four associations that exist in nature ( $N$. lolii, LpTG-2 and Gliocladiumlike on perennial ryegrass, $N$. coenophialum on tall fescue), and five artificial associations already obtained by other authors $(N$. lolii and LpTG-2 on tall fescue, $N$. coenophialum on perennial ryegrass and Epichloe festucae on both hosts).

Clay [11] suggested that for a Neotyphodium-grass association to be considered compatible, a viable endophyte must be seed transmitted at high frequency, preferably for more than one generation. In the present study, the fungus was transmitted to the seeds in ten cases out of the 11 studied. As was expected from the results of microscopical observations and re-isolations from the plants, the mycelium of Acremonium sp. (Lpr-1) was not found in the seeds. In addition, the transmission rate was low in two associations: Gliocladium-like endophyte on tall fescue and par- 
Table V. Detail of transmission of endophytes to seeds for the artificial associations $F$. arundinacea + Gliocladium-like and L.perenne + Neotyphodium coenophialum.

\begin{tabular}{|c|c|c|c|c|c|c|}
\hline Associations & Plants & $\begin{array}{l}\text { Ears or } \\
\text { panicles }\end{array}$ & $\begin{array}{l}\text { Number of } \\
\text { seeds E+ }\end{array}$ & $\begin{array}{l}\text { Number of } \\
\text { seeds E- }\end{array}$ & $\begin{array}{l}\text { Percentage of } \\
\text { infected seeds }\end{array}$ & $\begin{array}{c}\text { Confidence } \\
\text { interval }(\alpha=5 \%)\end{array}$ \\
\hline $\begin{array}{l}\text { Clarine }+ \\
\text { Gliocladium-like } \\
(\mathbf{L p}-80)\end{array}$ & $\begin{array}{c}4 \\
5 \\
\text { Grand total }\end{array}$ & $\begin{array}{c}1 \\
2 \\
3 \\
\text { total } \\
1 \\
2 \\
3 \\
\text { total } \\
1 \\
2 \\
3 \\
\text { total } \\
1 \\
2 \\
3 \\
\text { total } \\
1 \\
2 \\
3 \\
\text { total }\end{array}$ & $\begin{array}{c}21 \\
32 \\
24 \\
77 \\
16 \\
19 \\
15 \\
50 \\
16 \\
14 \\
13 \\
43 \\
0 \\
0 \\
0 \\
0 \\
0 \\
9 \\
7 \\
12 \\
28 \\
194\end{array}$ & $\begin{array}{c}17 \\
10 \\
14 \\
41 \\
26 \\
20 \\
32 \\
78 \\
26 \\
31 \\
30 \\
87 \\
34 \\
32 \\
37 \\
103 \\
12 \\
4 \\
7 \\
23 \\
332\end{array}$ & $\begin{array}{l}0 \% \\
\\
55 \% \\
37.4 \%\end{array}$ & $\begin{array}{l}{[0 ; 0.03]} \\
{[0.40 ; 0.69]} \\
{[0.33 ; 0.41]}\end{array}$ \\
\hline $\begin{array}{l}\text { Vigor }+ \\
\text { N. coenophialum } \\
\text { (Fa-6) }\end{array}$ & $\begin{array}{c}4 \\
\text { Grand total }\end{array}$ & $\begin{array}{c}1 \\
2 \\
3 \\
4 \\
\text { total } \\
1 \\
2 \\
3 \\
\text { total } \\
1 \\
2 \\
3 \\
\text { total } \\
1 \\
2 \\
3 \\
\text { total }\end{array}$ & $\begin{array}{c}7 \\
7 \\
4 \\
16 \\
34 \\
15 \\
12 \\
14 \\
41 \\
0 \\
0 \\
0 \\
0 \\
0 \\
0 \\
0 \\
0 \\
75\end{array}$ & $\begin{array}{c}29 \\
33 \\
30 \\
27 \\
119 \\
12 \\
27 \\
15 \\
54 \\
17 \\
11 \\
18 \\
46 \\
14 \\
22 \\
35 \\
71 \\
290\end{array}$ & $\begin{array}{l}22 \% \\
43 \%\end{array}$ & $\begin{array}{l}{[0.19 ; 0.25]} \\
{[0.33 ; 0.53]}\end{array}$ \\
\hline
\end{tabular}

ticularly $N$. coenophialum on perennial ryegrass ( 37.4 and $19.5 \%$, respectively). For these two associations, the counting of seeds with and without endophyte was effected separately on the different plants and the different ears or panicles of the same plant. In contrast with Wilson and Easton's results [39], we did not observe endophyte-free ears on endophyte-infected plants; the three ears observed on a given plant appeared either all endophyte-free or all infected. However, only a few plants were 
observed. Transmission of the endophytes through the following generations will be studied. However, most of the endophytes were seed transmitted at high frequency; the transmission rate to the seeds of perennial ryegrass was $100 \%$ for three isolates belonging to the species: $N$. lolii, LpTG-2 and $E$. festucae. If the first two taxa are natural endophytes of perennial ryegrass, it is not the case for E. festucae.

Several reactions of incompatibility were observed. The main criterion for compatibility was the presence or absence of modifications affecting the hyphae. Hyphae of $N$. coenophialum were highly vacuolated in many of the $L$. perenne plants with which this endophyte formed associations. This study confirms the incompatibility affecting endophytic hyphae, previously observed in certain associations of $F$. arundinacea endophytes in $L$. perenne $[4,17]$. The possibility that an accumulation of host-produced antifungal compounds in the hyphae of the L. perenne/N. coenophialum association may contribute to the degeneration of the cytoplasm and plasma membrane cannot be discarded. However, if antifungal compounds were present, according to Koga et al. [17], they were not the product of a hypersensitive reaction as often occurs in plant/fungus incompatibility, since surrounding host cells showed no ultrastructural changes. This fungal reaction of incompatibility was not linked to the presence of stunted tillers or to the death of infected plants.

No change affecting the hyphae was observed for the tall fescue/LpTG-2 associations. However, stunted tillers were often observed in this association, which must be put together with the high frequency of plants that did not survive: $62 \%$ of fescue plants infected by LpTG-2 failed to survive for more than 4 months. Christensen [4] reported that in the association of tall fescue with LpTG-2, the presence of stunted tillers was linked to necroses at the base of the tillers, in meristematic tissues. We did not investigate the associations at this level.

A high frequency of tall fescue plants infected with Gliocladium-like were able to survive, although these plants were often stunted. Two phenomena were observed for this association. i) The presence of endophyte-free tillers that did not appear to be associated with incompatibility. It should be noted that these endophyte-free tillers also develop in natural associations [15]. Endophyte-free tillers presumably develop from axillary buds which have not been colonized by the endophyte. The mechanism for this failure is unclear [4]. ii) The endophyte did not persist for more than a few months in some unstunted plants of tall fescue initially infected.

Such a deleterious effect of p-endophytes on their hosts has been reported even in the case of natural associations [35].

The different e-endophytes used in this study appear as only partially host specific. Such a result confirms Christensen's results which showed that the taxa identified in $L$. perenne, $F$. arundinacea and $F$. pratensis were not specific to their natural hosts [4]. This author suggested that the lack of host specificity probably reflected the very close genetic relationships between perennial ryegrass, tall fescue and meadow fescue. Koga et al. [17] also showed that $N$. lolii, $N$. coenophialum and LpTG-2 are not specific to their natural hosts. However, in the present study, associations with endophytes from more distant grass species such as Bromus erectus and Koeleria cristata could also be obtained. However, the plants with Epichloe bromicola died in the greenhouse a few months after infection. The plants with $E$. festucae from $K$. cristata $(\mathrm{Kc}-1)$ had not been conserved after the first observation, the isolate Frn-1 (from Festuca rubra ssp. nigrescens) having been taken as representative of the species $E$. festucae. On the other hand, it was not possible to obtain associations of tall fescue and perennial ryegrass with Epichloe spp. from Dactylis glomerata, Poa nemoralis and Puccinellia distans.

We confirm in the present study that it is possible to transfer certain endophytes to grasses which are not their natural hosts. The possibility of introducing selected strains of endophytes into commercial varieties of perennial ryegrass has been investigated for several years in New Zealand, this strategy being extensively analysed in a recent review by Fletcher and Easton [13]. These authors showed 
that the selection of suitable strains (possibly without lolitrem or ergovaline) and their introduction into new hosts are only preliminary steps on the way to obtaining commercial associations, which requires the study of the interactions between the selected strain and commercial cultivars, the influence of the environment (including extreme climatic sequences) on the synthesis of mycotoxins, and the behaviour of the associations in the field. The strains selected in New Zealand are likely to belong to $N$. lolii (and LpTG-2?); however, our results, after those of Latch and Christensen [20], Koga et al. [17], Christensen [4], Christensen et al. [7], show that it could be possible to enlarge the selection of strains to endophytes of other grass species. As regards Lolium perenne, in addition to the two natural e-endophytes of this host, the selection could also concern Epichloe festucae, a species which, in our experiment, was $100 \%$ transmitted to the seeds of perennial ryegrass and did not show any harmful effect on this host. Recent investigations found ergovalin in Festuca rubra (but not in $F$. gigantea), infected by E. festucae. [2, 3]. However, E. festucae, as a sexed fungus, is likely to be highly variable (as was shown by Christensen et al. [7]) and it will be interesting to study its variability as concerns mycotoxin synthesis. In contrast, Neotyphodium coenophialum, appeared poorly adapted to Lolium perenne.

Tall fescue generally appears less accessible than perennial ryegrass for endophytes which are not its natural symbionts. However, the selection of endophytes suitable for this host could concern (in addition to its natural endophyte Neotyphodium coenophialum), Epichloe festucae and N. lolii.

\section{REFERENCES}

[1] Bacon C.W., Porter J.K., Robbins J.D., Luttrell E.S., Epichloe typhina from toxic tall fescue grasses, Appl. Environ. Microbiol. 34 (1990) 576-581.

[2] Bazely D.R., Vicari M., Emmerich S., Filip L., Lin D., Inman A., Interactions between herbivores and endophyte-infected Festuca rubra from the Scottish islands of St. Kilda, Benbecula and Rum, J. Appl. Ecol. 34 (1997) 847-860.
[3] Bush L.P., Wilkinson H.H., Schardl C.L., Bioprotective alkaloids of grass-fungal endophyte symbioses, Plant Physiol. 114 (1997) 1-7.

[4] Christensen M.J., Variation in the ability of Acremonium endophytes of Lolium perenne, Festuca arundinace $a$ and $F$. pratensis to form compatible associations in the three grasses, Mycol. Res. 99 (1995) $466-470$.

[5] Christensen M.J., Latch G.C., Tapper B.A., Variation within isolates of Acremonium endophytes from perennial rye-grasses, Mycol. Res. 95 (1991) 918-923.

[6] Christensen M.J., Leuchtmann A., Rowan D.D., Tapper B.A., Taxonomy of Acremonium endophytes of tall fescue (Festuca arundinacea), meadow fescue $(F$. pratensis) and perennial rye-grass (Lolium perenne), Mycol. Res. 97 (1993) 1083-1092.

[7] Christensen M.J., Ball O.J.P., Bennett R.J., Schardl C.L., Fungal and host genotype effects on compatibility and vascular colonization by Epichloe festucae, Mycol. Res. 101 (1997) 493-501.

[8] Clark E.M., White J.F., Patterson R.M., Improved histochemical techniques for the detection of Acremonium coenophialum in tall fescue and methods of in vitro culture of the fungus, J. Microbiol. Methods 1 (1983) 149-155.

[9] Clay K., Fungal endophytes of grasses: a defensive mutualism between plants and fungi, Ecology 69 (1988) 10-16.

[10] Clay K., Recent advances in the ecology of endophytes, Hume D.H. (Ed.), Proceedings of the Second International Symposium on Acremonium / Grass Interactions, Palmerston North, New Zealand, 1993, pp. 11-30.

[11] Clay K., The ecology and evolution of endophytes, Agric. Ecosys. Environ. 44 (1993) 39-64.

[12] Fletcher L.R., Harvey I.C., An association of a Lolium endophyte with ryegrass staggers, N. Z Vet. J. 29 (1981) 185-186.

[13] Fletcher L.R., Easton H.S., The evaluation and use of endophytes for pasture improvement, in: Bacon C.W., Hill N.S. (Eds.), Third International Symposium on Neotyphodium/Grass Interactions, Athens, Georgia. Proceedings Plenum Press, New York, 1997, pp. 209-225.

[14] Glenn A.E., Bacon C.W., Price R., Hanlin R.T., Molecular phylogeny of Acremonium and its taxonomic implications, Mycologia 88 (1996) 369-383.

[15] Hinton D. M., Bacon C.W., The distribution and ultrastructure of the endophyte of toxic tall fescue, Can. J. Bot. 63 (1985) 36-42. 
[16] Johnson M.C., Bush L.P., Siegel M.R., Infection of tall fescue with Acremonium coenophialum by means of callus cultures, Plant Dis. 70 (1986) 380-382.

[17] Koga H., Christensen M.J., Bennett R.J., Incompatibility of some grass / Acremonium endophyte associations, Mycol. Res. 97 (1993) 1237-1244.

[18] Koga H., Hirai Y., Kanda K., Tsukiboshi T., Uematsu T., Successive transmission of resistance to Bluegrass Webworm to perennial ryegrass and tall fescue plants by artificial inoculation with Acremonium endophytes, J. A. R. Q. 31 (1997) 109-115.

[19] Latch G.C.M., Christensen M.J., Samuels G.J., Five endophytes of Lolium and Festuca in New Zealand, Mycotaxon 20 (1984) 535-550.

[20] Latch G.C.M., Christensen M.J., Artificial infection of grasses with endophytes, Ann. Appl. Biol. 107 (1985) 17-24.

[21] Leuchtmann A., Systematics, distribution and host specificity of grass endophytes, Nat. Toxins 1 (1992) 150-162.

[22] Leuchtmann A., Clay K., Isozyme variation in the Acremonium/Epichloe fungal endophyte complex, Phytopathology 80 (1990) 1133-1139.

[23] Leuchtmann A., Clay K., Nonreciprocal compatibility between Epichloe typhina and four host grasses, Mycologia 85 (1993) 157-163.

[24] Leuchtmann A., Schardl C.L., Siegel M.R., Sexual compatibility and taxonomy of a new species of Epichloe symbiotic with fine fescue grasses, Mycologia 96 (1994) 802-812.

[25] Leuchtmann A., Schardl C.L., Mating compatibility and phylogenetic relationships among two new species of Epichloe and other congeneric European species, Mycol. Res. 102 (1998) 1169-1 182.

[26] Malinowski D., Leuchtmann A., Schmidt D., Nosberger J., Growth and water status in meadow fescue is affected by Neotyphodium and Phialophora species endophytes, Agron. J. 89 (1997) 673-679.

[27] Morgan-Jones G., Gams W., Notes on Hyphomycetes. An endophyte of Festuca arundinacea and the anamorph of Epichloe typhina, new taxa in one of the two new sections of Acremonium, Mycotaxon 15 (1982) 311-318.

[28] Naffaa W., Ravel C., Guillaumin J.-J., Morphological and molecular variability among Acremonium isolates from 22 species of Poaceae in France, in: Krohn K., Paul V.H. (Eds.), Proceedings of the Second International Conference on Harmful and Beneficial Microorganisms in Grassland, Pastures and Turf, Paderborn, Germany, 1995, pp. 185-200.
[29] Naffaa W., Ravel C., Guillaumin J.-J., A new group of endophytes in European grasses, Ann. Appl. Biol. 132 (1998) 211-226.

[30] Ravel C., Wartelle D., Charmet G., Artificial infection of tillers from perennial ryegrass mature plants with Acremonium endophytes, in: Krohn K., Paul V.H., Thomas J. (Eds.), Proceedings of the First International Conference on Harmful and Beneficial Microorganisms in Grassland, Pastures and Turf, Paderborn, Germany, 1994, pp. 123-125.

[31] Raynal G., Observations françaises sur les Acremonium, champignons endophytes des graminées fourragères, Fourrages 126 (1991) 225-237.

[32] Rowan D., Lolitrems, peramine and paxilline: mycotoxins of the ryegrass / endophyte interaction, Agric. Ecosyst. Environ. 44 (1993) 103-122.

[33] Schardl C.L., Epichloe species: Fungal Symbionts of Grasses, Annu. Rev. Phytopathol. 34 (1996) 109-130.

[34] Schardl C.L., Liu J.S., White J.F., Finkel R.A., Siegel M.R., Molecular phylogenetic relationships of nonpathogenic grass mycosymbionts and clavicipitaceous plant pathogens, Plant Syst. Evol. 178 (1991) $27-41$.

[35] Schmidt D., Effects of Acremonium uncinatum and a Phialophora-like endophyte on vigour, insect and disease resistance of meadow fescue, in: Hume D. H. (Ed.), Proceedings of the Second International Symposium on Acremonium / Grass Interactions, Palmerston North, New Zealand, 1993, pp. 185-187.

[36] Siegel M.R., Latch C.G.M., Johnson M.C., Fungal endophytes of grasses, Annu. Rev. Phytopathol. 25 (1987) 293-315.

[37] Siegel M.R., Schardl C.L., Phillips T.D., Incidence and compatibility of nonclavicipitaceous fungal endophytes in Festuca and Lolium grass species, Mycologia 87 (1995) 196-202.

[38] VanHeeswijch R., MacDonald G., Acremonium endophytes in perennial ryegrass and other pasture grasses in Australia and New Zealand, Aust. J. Agric. Res. 43 (1992) 1683-1709.

[39] Wilson S.M., Easton, H.S., Seed transmission of an exotic endophyte in tall fescue, in: Bacon C.W., Hill N.S. (Eds.), Third International Symposium on Neotyphodium/Grass Interactions, Athens, Georgia. Proceedings Plenum Press, New York, 1997, pp. 281-283. 